\title{
CHOROBA JAKO ZJAWISKO SPOLECZNE. ANALIZA WALKI Z AFRYKAŃSKIM POMOREM ŚWIŃ
}

\section{AFRYKAŃSKI POMÓR ŚWIŃ}

To wirusowa choroba powodowana przez Asfivirus (ASF), jedynego przedstawiciela rodziny Asfarviridae. Ma on kształt dwudziestosześcianu, nukleokapsyd zawiera DNA i jest otoczony osłonka; ASF jest jedynym znanym wirusem namnażającym się przez replikację DNA i przenoszonym przez stawonogi ${ }^{1}$. Jest to wirus wysoce odporny na temperaturę, procesy gnilne, wędzenie, krótkotrwałe gotowanie, wysychanie, w mrożonym mięsie potrafi przetrwać nawet 1000 dni, w suszonym mięsie i tłuszczu - 300, a w wędzonym 30 dni. Przeżywa w kale zarażonych zwierząt 11 dni, w krwi - 18 miesię$\mathrm{cy}^{2}$. Przywołani autorzy wskazuja, że skutecznymi środkami dezynfekcyjnymi przeciwko wirusowi sa: detergenty, podchloryn sodu, aldehyd glutarowy, środki zasadowe, rozpuszczalniki lipidowe oraz Virkon S. Wirus jest śmiertelnie groźny dla świń i świniowatych, powoduje bardzo silną wybroczynowość, zapalenie osierdzia, zapalenia płuc i stawów, co skutkuje wysoka gorączką u chorych osobników. Inne objawy to brak apetytu, zapalenie spojówek, kaszel, pienisty wypływ z nosa, biegunka, wymioty. Moga wystapić drgawki. Choroba ma najczęściej przebieg ostry. Śmiertelność prawie zawsze wynosi 100\%. Do diagnostyki wykorzystuje się badania na wykrywanie obecności przeciwciał oraz testy wykrywajace wirusa.

W informacjach generowanych i publikowanych przez Państwową Inspekcję Weterynaryjna i służby weterynaryjne w ogóle oraz w przekazach medialnych podaje się informacje na temat tego, że dzik jest wektorem choroby (przenosi wirusa), co jest prawda, ale nie cała. Wektorami wirusa moga być też ludzie, psy czy koty, a także kleszcze (obrzeżki tzw. soft ticks) z rodzaju Ornithodoros ${ }^{3}$, które jednak nie występują w Polsce. Prowadzone są badania, które maja dostarczyć jednoznacznych informacji, czy inne rodzaje kleszczy występujace między innymi w Polsce, moga być wektorami dla wirusa ASF ${ }^{4}$. Badania Franta, Woźniakowskiego i Pejsaka wykazały związek pomiędzy zwiększoną liczbą przypadków choroby ASF a podniesioną liczebnością dzików, ale autorzy nie wskazują jaki jest ten związek, a szczególnie czy ma

\footnotetext{
1 Woźniakowski et al. (2016).

2 Markowska-Daniel, Pejsak (2014).

3 Por. Brown, Bevins (2018).

${ }^{4}$ Frant, Woźniakowski, Pejsak (2017): 377.
} 
charakter przyczynowo-skutkowy, tzn. czy pomiędzy wspomnianymi dwoma zjawiskami istnieje relacja wynikania, czy też zachodzi między nimi jedynie współwystępowanie, co oczywiście nie jest jednoznaczne z wynikaniem. Dziwi, że autorzy formułują następujące twierdzenie: „Obecność ASFV wśród dzików i na terenie okalającym chlewnie znacząco podnosi ryzyko przeniesienia wirusa $\mathrm{z}$ lasu do świń przez bezpośredni kontakt z zarażonymi zwierzętami lub ich mięsem". Twierdzenie takie jest o tyle nieprawdziwe, że w zasadzie nie ma realnych możliwości, żeby dziki bezpośrednio kontaktowały się ze świniami. Zawsze jest do tego potrzebny inny wektor. Badania wskazują za to, że wektorem ASFV w Polsce może być bolimuszka jesienna (Stomoxys calcitrans) z rodziny muchówek. Autorzy pisza, że jest mało prawdopodobne, by kleszcze występujące w Polsce przyczyniały się do roznoszenia ASFV, brak jednak jednoznacznych wyników badań dających pewność co do tego, jakie mogą być rzeczywiście wektory dla ASFV na naszym terenie.

W Polsce w lutym 2014 r. wykryto pierwsze przypadki ASF u dzików, które prawdopodobnie przedostały się z Białorusi. Do końca 2015 r. wszystkie przypadki choroby zlokalizowane były w pobliżu wschodniej granicy Polski. Jednak w 2016 r. wirus rozszerzył się na środkowe tereny kraju. Do końca lipca 2018 r. w Polsce były 182 ogniska choroby i w tym samym roku wykryto 3300 przypadków ASF u dzików. W listopadzie 2019 r. w województwie lubuskim znaleziono 20 dzików z ASF, a w grudniu kolejne ognisko afrykańskiego pomoru świń odkryto w wielkopolskim Wolsztynie.

Pojawienie się ASF jest ważnym problemem nie tylko weterynaryjnym i nie tylko gospodarczo-ekonomicznym, ale także społecznym. Warto spojrzeć na to zjawisko szerzej, ponieważ jest ono wieloaspektowe i obejmuje znacznie więcej obszarów, niż można się spodziewać.

\section{CHOROBA JAKO NARZĘDZIE GENEROWANIA LĘKÓW}

Susan Sontag poświęciła dwa swoje eseje analizowaniu choroby jako metafory ${ }^{5}$. Wskazywała tam, że choroba nie tylko jest medycznie definiowanym stanem zaburzenia dobrostanu organizmu, ale że niesie ze soba wiele społecznie i kulturowo generowanych znaczeń i naznaczeń (ten wątek eksploatował także Erving Goffman ${ }^{6}$, na którego pracę Sontag również się powołuje ${ }^{7}$. Sontag interesowała się szczególnie trzema chorobami: gruźlica, rakiem, czyli nowotworami, a potem AIDS (poświęca też uwagę syfilisowi). I wskazywała, że pojęcie choroby może stać się narzędziem oddziaływania tak na samego pacjenta, jak i na społeczne otoczenie przez generowanie i pogłębianie irracjonalnych lęków, które są osadzone w archetypicznych obawach przed obcym i nieznanym. Choroby, szczególnie te będące przedmiotem zainteresowania

\footnotetext{
${ }^{5}$ Sontag (1979) i (1989; wyd. polskie 2016).

6 Goffman (2005).

7 Por. Sontag (1989): 15.
} 
Sontag, są utożsamiane ze złem, niewidocznym napastnikiem, potworem pożerającym organizm, wyrokiem. Autorka wskazuje, że słowo „rak” bywa „wykorzystywane do uśmiercania pacjentów”, którzy nie są skorzy do odejścia z tego świata. Szczególnie nieznane źródła zakażenia choroba, jej transmisji, trudność lub niemożność leczenia, generują w ludziach lęk i powoduja stygmatyzację chorych lub nosicieli wirusa. Ten mechanizm oddziaływania na opinię publiczna w charakterystyczny sposób wykorzystuja ruchy totalitarne: w nazistowskiej retoryce Żydzi przyrównywani byli do raka, którego należy wyciać, by ocalić zdrowe tkanki organizmu. Na przełomie XIX i XX w. jednym z wątków eksploatowanych w działaniach antysemickich było eskalowanie poczucia zagrożenia syfilisem - Sontag przywołuje opinię Wilhelma Reicha (austriackiego psychiatry, doktora nauk medycznych i psychoanalityka) z 1933 r., który wskazywał, że „irracjonalny lęk przed syfilisem był jednym z głównych źródeł Narodowego Socjalizmu i jego antysemityzmu"8. Lęk przed chorobami po dziś dzień jest wykorzystywany przez autorytarnych przywódców jako narzędzie budujące poparcie dla ograniczania możliwości wjazdu dla emigrantów i uchodźców, czy po prostu przedstawicieli wybranych państw. Taka ksenofobiczna propaganda, jak wskazuje Sontag, ma już długa historię wykorzystywania (w XIX w. wykorzystywano do tego cholerę, żółtą febrę, czy gruźlicę). Lęk budowany na wyimaginowanym zagrożeniu, umiejętnie podsycany, pozwala zyskiwać przychylność dla określonych rozwiązań. W tej strategii najczęściej wskazuje się, że choroby pochodzą „skądinąd”, że są niesione właśnie przez ten pierwiastek obcości. Te inne miejsca - albo są odległe geograficznie (a przynajmniej są wyraźnie oddzielone), albo są odległe mentalnie lub statusowo (np. są ubogie). Choroba jest więc wiązana z obcościa, ubóstwem, odmiennością myślenia, kontekstem niepożądanym.

Powyższe wskazywane przez Sontag prawidłowości obserwujemy także w przypadku afrykańskiego pomoru świń: jest to choroba przywleczona skądinąd (zza wschodniej granicy polskiej, choć pochodzi z Afryki); jest przenoszona przez „Innego” - nie człowieka, ale dzika, i to nie dzika lokalnego, ale dzika migrującego z terytorium innego kraju. Choroba jest śmiertelna dla zwierząt, dotąd nie opracowano na nią lekarstwa itd. i proponuje się w Polsce, by ja zwalczać przez bezpośrednie zaangażowanie wojska do odstrzałów sanitarnych - a więc przez zmilitaryzowane działania. O afrykańskim pomorze świń wspomina Sontag w AIDS and Its Metaphors ${ }^{9}$ - wskazując, że już sama nazwa choroby określajacca jej pochodzenie wzmacnia negatywne nastawienie do Afryki, innego - ubogiego i „prymitywnego” kontynentu, z którego przychodzi do Europy zagrożenie. Zagrożenie jest więc z zewnątrz, z Afryki.

Dzisiaj niektóre wystapienia polityków także łączą niechciane kategorie społeczne ludzi z wizją roznoszenia przez nich chorób. Sa to na tyle silne oddziaływania o psychologicznym charakterze, że poczucie lęku przed mniej lub bardziej zdefiniowanymi chorobami jest automatycznie generalizowane na tych, którzy te choroby mogą przenosić, przy czym zupełnie bez znaczenia

\footnotetext{
8 Sontag (1979): 59.

9 Sonrag (1989): 52.
} 
jest, czy rzeczywiście taka droga transmisji choroby istnieje. Oczywiście wygenerowanie lęku w opinii publicznej skłania ją do przychylności wobec radykalnych rozwiązań, co ułatwia wprowadzanie rozstrzygnięć niemożliwych do zastosowania w sytuacji, gdy nie istnieją obawy społeczne. Ten sam mechanizm generalizowania lęku ${ }^{10}$ został zastosowany w przypadku afrykańskiego pomoru świń, przy czym podmiotem, na którego przenoszona jest społeczna niechęć ludzi (a konkretnie: wybranych przedstawicieli szczególnej kategorii społecznej - producentów trzody chlewnej oraz drobnych rolników), jest dzik. Oczywiście pozostaje pytaniem otwartym, czy faktycznie producenci trzody tak właśnie negatywnie postrzegają dziki, czy też jest to wizerunek kreowany medialnie w odpowiedzi na czyjeś potrzeby.

Pojawienie się zagrożenia w postaci choroby wymusza konieczność walki z nią. Zjawisko militaryzowania zagrożeń o biologicznym charakterze też jest znane zarówno w codziennej praktyce społecznej, jak i w propagandzie politycznej, tak więc militaryzacja pojawia się także w odniesieniu do chorób i ich zwalczania ${ }^{11}$. Terminologia tu stosowana jednoznacznie nawiązuje do prowadzenia wojny (wypowiedzieć wojnę chorobie, zwalczać chorobę, choroba atakuje, inwazyjna choroba i wiele innych określeń). Taki sposób opisywania chorób pojawił się w medycynie w latach osiemdziesiątych XIX w., kiedy odkryto, że bakterie sa czynnikami powodujacymi choroby. Te militarne metafory przyczyniają się szczególnie mocno do stygmatyzowania niektórych chorób, a przez analogię - także osób na nie chorujących. Sontag w AIDS and Its Metaphors wskazuje ciekawy wattek o podobnym charakterze: omawia włoską kampanię z lat dwudziestych XX w. nawołująca do „Wojny przeciwko muchom” (chodziło o zwalczanie gruźlicy ${ }^{12}$. Konwencja militaryzacji została także zastosowana do czterech plag, z którymi walczyli Chińczycy w latach $1958-1962^{13}$ oraz w Polskiej Rzeczpospolitej Ludowej podczas walki ze stonką ziemniaczana, do której to zaangażowano nawet lotnictwo.

\section{KONCEPCJA ,JEDNEGO ZDROWIA”}

Choroby zwierząt nie są problemem dotyczacym tylko zwierzą i tylko lekarzy weterynarii. Powiązanie populacji ludzkich z populacjami nie-ludzkimi, ich koegzystencja współistnienie sa dzisiaj silniejsze niż kiedykolwiek wcześniej, pomimo że - jak wskazuje wielu autorów - ludzkie relacje z innymi zwierzętami przyjmuja postać bardzo szeroko rozumianej konsumpcji ${ }^{14}$. Te wzajemne, złożone związki doskonale opisuje koncepcja „jednego świata, jednego zdrowia" (,one world, one health") ${ }^{15}$. Idea jednego zdrowia proponu-

\footnotetext{
10 Por. Mamzer (2018).

11 Sontag (1979): 10, 64.

12 Sontag (1989): 10.

13 Holst (2016): $43 \mathrm{n}$.

14 Por. de Mello (2012).

15 Por. Destoumieux-Garzón et al. (2018).
} 
je, by analizować zdrowie świata ożywionego jako całości, na którą składaja się przynajmniej trzy integralne składniki, którymi sa: zdrowie ludzi, zdrowie zwierząt nie-ludzkich i zdrowie roślin. Zdrowie tych trzech grup organizmów żywych jest ze wzajemnie uwarunkowane siecia powiązań działających zwrotnie na pozostałe elementy. Koncepcję ,jednego zdrowia” należy rozumieć więc jako holistyczne spojrzenie na cały świat ożywiony, który oczywiście osadzony jest w swoim geograficzno-przestrzennym kontekście.

W takim rozumieniu nie można izolować jednego składnika i poddawać go oddziaływaniom, licząc na to, że nie będą one dotyczyły pozostałych elementów, wyrwanie bowiem któregokolwiek elementu z kontekstu w warunkach empirycznych nie jest możliwe. Tego rodzaju „ćwiczenia” są oczywiście możliwe na poziomie teoretycznym, jednak na poziomie praktyki, jest to nierealne i zawsze eliminowanie kontekstu będzie prowadzić do negatywnych skutków. W ramach koncepcji jednego zdrowia zakłada się, że wzajemne powiązania istniejące pomiędzy różnymi procesami warunkującymi życie na Ziemi w drugiej dekadzie XXI w. absolutnie eliminują możliwość stosowania rozwiązań o charakterze incydentalnym. Tego rodzaju zachowania nie przynoszą oczekiwanych skutków i stają się jedynie formą atrapowego działania uspokajającego (?) opinię publiczną. Nie mogą one jednak przynieść satysfakcjonujących długofalowych skutków. Co więcej - zastosowanie każdej metody interwencji w złożony system zdrowia powinien być oparty na rzetelnej, merytorycznej analizie prognozującej zmiany wywołane podjętym rodzajem działania.

Rozwinięciem idei ,jeden świat, jedno zdrowie” stało się podejście proponujące myślenie szersze, a mianowicie ,jedno zdrowie, jeden dobrostan”. Ma ono podkreślać, że nie tylko fizyczno-fizjologiczny wymiar zdrowia jest istotny, ale że ważne jest też myślenie o wymiarach psychologicznych zdrowia, które często w sposób nieoczywisty są przekładalne na zdrowie somatyczne organizmów żywych.

Koncepcja jednego zdrowia ma w istocie unaoczniać nierozerwalne związki, które łączą wszystkie gatunki żywe i ma promować holistyczne myślenie o świecie. Tego rodzaju podejście jest szczególnie istotne dla lekarzy weterynarii - znosi bowiem, obecny w weterynaryjnych kodeksach etycznych niektórych krajów, podział na zdrowie ludzi i na zdrowie zwierząt. Nie da się dbać o jedno, ignorujac drugie. Ta niby oczywista (?) prawda, nie jest jednak powszechnie zrozumiała, jako że nadal funkcjonują w naszym społeczeństwie mentalne dualistyczne dychotomie separujace te dwa obszary, choć dzisiaj nikt racjonalnie myślaccy już nie ma wątpliwości co do biologicznej wspólnoty ludzi i innych zwierząt.

Zdrowie, traktowane holistycznie jako stan pożądanej równowagi somatyczno-psychologicznej obecnej w całym świecie ożywionym ${ }^{16}$, jest zagrożone nie tylko przez nasilający się proces cyrkulacji różnego rodzaju infekcji i chorób, ale także przez narastająca lekooporność, zanieczyszczenie środowiska

${ }_{16}$ Por definicja zdrowia według Światowej Organizacji Zdrowia WHO: „stan pełnego fizycznego, umysłowego i społecznego dobrostanu a nie tylko brakach choroby czy niepełnosprawności”, <https://www.who.int/about/who-we-are/frequently-asked-questions>. 
oraz rozwój wieloczynnikowych chorób o chronicznym charakterze. Te zjawiska powoduja, że ryzyka zagrażające zdrowiu mają charakter globalny i wynikają bezpośrednio ze stylów życia i stylów konsumpcyjnych ludzi.

Masowa, nadmierna konsumpcja produktów niekorzystnie wpływających na zdrowie staje się dzisiaj bezpośrednia przyczyna załamania się zdrowia ludzkich populacji. Można już jednoznacznie powiedzieć, że masowa produkcja zwierzęca, która miała zaspokoić konsumpcyjne potrzeby ludzi, stała się weberowską żelazną klatką racjonalności, przekształcająca pozornie idealne rozwiązania w rodzaj więzienia, z którego nie ma ucieczki. Proces tej produkcji jest już tak „zoptymalizowany”, że wydaje się osiagać swoje maksymalne możliwości, a maszyneria zarządzania tym skomplikowanym mechanizmem pracuje na pełnych obrotach. Idea masowej produkcji zwierzęcej jest wprost oparta na ideach naukowego zarządzania Fredericka Winslowa Taylora i Henry'ego Forda. Racjonalizacja produkcji, minimalizowanie kosztów przy maksymalizacji zysków, podział procesu produkcyjnego na mniejsze etapy wykonywane w warunkach ścisłej kontroli ilościowej i jakościowej oraz pozostałe zasady stosowania taśmowego sposobu organizacji pracy, zostały w XIX w. przeniesione na grunt produkcji zwierzęcej, co przybrało postać budowania przemysłowych ubojni w rejonie Chicago w Stanach Zjednoczonych Amery$\mathrm{ki}^{17}$. Rozwiązania te wydawały się doskonałymi sposobami zaspokajania popytu na produkty odzwierzęce. Szybko jednak okazało się, że tak przedmiotowe traktowanie zwierząt konfrontuje teoretyczne założenia naukowej organizacji pracy z zasadami regulującymi funkcjonowanie organizmów żywych. Zaczęło nasilać się pojawianie się chorób, wzrosła liczba upadków zwierząt, znacząco obniżył się ich dobrostan. Dopiero niedawno ludzie zorientowali się, że to wszystko wpływa nie tylko na dobrostan samych zwierzą, ale także na nasz ludzki dobrostan. I w istocie rzeczy trzeba z przykrością stwierdzić, że to właśnie obniżenie dobrostanu ludzi korzystających z produktów odzwierzęcych skłania człowieka do pochylania się nad dobrostanem zwierząt. Wydaje się jednak, że wzrost poziomu i zakresu świadomości ludzi jest skokowy. Dzisiaj już coraz częściej zastanawiamy się nie tylko nad tym, co zyskują ludzie, kiedy zapewnia się dobrostan zwierzętom. Do powszechnej świadomości społecznej przekradają się wątki wskazujące, że produkcja zwierzęca jest zagrożeniem (a nie zbawieniem, jak się długo wydawało) dla całej ludzkości, a zwierzęta jako podmioty nie moga być traktowane przedmiotowo, jest to bowiem zachowanie i nieetyczne, i nieuzasadnione żadna koniecznością typu przetrwanie. Dbałość o dobrostan zwierząt ma być wartością autoteliczna.

Zintensyfikowana produkcja wymagająca znacznej koncentracji wielu osobników na małych obszarach stała się bezpośrednią przyczyną pojawiania się chorób dziesiątkujących zwierzęta. Taki stan rzeczy wynika właśnie z nienaturalnego stłoczenia zwierząt, co nie tylko w oczywisty sposób ułatwia rozprzestrzenianie się chorób ze względu na bezpośrednią styczność zwierząt ze sobą. Zwierzęta stłoczone na małych obszarach doświadczają dyskomfortu wynikającego z przegęszczenia. Taki długotrwały stres prowadzi do obniżenia

${ }^{17}$ Por. Roncaglia (2006); Harrison (2013). 
zwierzęcej odporności i podnosi podatność na infekcje. Dobrostan tak utrzymywanych zwierząt jest też obniżany przez inne zjawiska: przyspieszony, nienaturalnie szybki tucz (wspomagany podawanie środków przyspieszających wzrost, o ile to zgodne $\mathrm{z}$ legalnymi regulacjami w danym kraju); maksymalizowanie efektywności produkcji przez selekcję zwierząt w pożądanym kierunku (podnoszenie mleczności, nieśności itd.); optymalizację kosztów bezpośrednich przez ograniczanie możliwości zaspokojenia potrzeb wynikających z etogramu zwierząt, które z punktu widzenia krótkowzrocznego producenta nie sa potrzebne (np. ograniczanie przestrzeni, uniemożliwienie naturalnych zachowań rozrodczych - np. budowy gniazd, i wielu innych zachowań spełniających ważne funkcje społeczne i psychologiczne); generowania schorzeń i chorób wynikających z traktowania zwierząt jako produktu: konieczności minimalizowania strat ekonomicznych wynikających z pojawiania się chorób oraz upadków zwierząt (co wymusza prewencyjne stosowanie antybiotyków). Wszystko to doprowadziło do falowego pojawiania się chorób narażajacych sektor produkcji zwierzęcej na szkody, zwierzęta na cierpienie, a ludzi na zagrożenie zdrowia. W ostatnich latach w ten sposób doświadczyliśmy gąbczastej encefalopatii bydła (BSE), ptasiej grypy czy obecnie afrykańskiego pomoru świń.

\section{CHYBIONE PRÓBY INCYDENTALNYCH INTERWENCJI}

Jak pokazują niektóre szczególnie spektakularne przykłady realizowanej przez człowieka inżynierii w ramach „zarządzania populacjami” wybranych gatunków żywych, tego rodzaju doświadczenia kończą się często nieprzewidywalnie tragicznymi skutkami. Chyba najbardziej spektakularnym przykładem takiej sytuacji jest prowadzona w Chińskiej Republice Ludowej w latach 1958-1962 walka z czterema plagami. Była ona społeczno-polityczną kampanią zmierzajaccą do podniesienia poziomu higieny w Chinach i koncentrowała się na eliminacji gatunków określonych przez rząd jako szkodniki: szczurów, wróbli, komarów i much. Dla biologicznego myślenia jest oczywiste, że nadawanie gatunkowi etykiety „szkodliwego” jest antropocentryczna praktyka społeczna, rodzajem społecznej umowy, niemajacej rzeczywistego pokrycia w świecie biologicznym, ale mającej bezpośrednie skutki dla uruchamiania ludzkich działań wobec tak zakwalifikowanego gatunku. Szczególnie negatywnymi skutkami (dla ludzi) zakończyła się kampania tępienia wróbli, która polegała na tym, że Chińczycy płoszyli ptaki szukające odpoczynku, a nadmierny wysiłek i niemożność regeneracji prowadziły do śmierci ptaków z wycieńczenia. Założenia kampanii planowanej od 1956 r. zostały opublikowane w dokumencie „Wskazówki o zwalczaniu czterech plag i dyskusji nad higieną” sygnowanym przez Komitet Centralny Komunistycznej Partii Chin oraz Radę Państwa. Plan miał być realizowany przez chłopów, ale był także wspierany przez działania w miastach. Polegał na generowaniu hałasu za pomoca zwykłych przedmiotów codziennego użytku, niszczeniu gniazd i zabijaniu ptaków za pomoca proc, wkrótce doprowadziło do skutecznego zmniejszenia populacji 
wróbli, co jednak wpłynęło znacząco na zwiększenie się populacji szarańczy niszczącej plony. Ostatecznie wybicie wróbli przyczyniło się do niszczącego działania szarańczy na zbożach, a w konsekwencji tych zajść z głodu zmarło 20-40 milionów ludzi (niektóre źródła podają liczbę nawet 70 milionów osób ${ }^{18}$. Negatywne zmiany w strukturze społeczności ludzkich w Chinach obejmowały nie tylko wzrost poziomu śmiertelności, lecz także obniżenie przyrostu naturalnego na skutek niedożywienia i głodu, które bezpośrednio wpływały na fizyczne i fizjologiczne funkcjonowanie kobiet, ale które też wymuszały migracje „za chlebem”, rozbijając tradycyjne funkcjonowanie rodzin ${ }^{19}$.

Pomysł eliminacji wróbli jednoznacznie jest wskazywany nie tylko jako przykład zgubnych ingerencji ludzkich w ekosystem, ale też jako negatywny przykład konsekwencji funkcjonowania totalnych systemów władzy, w których z powodu ograniczania wolności słowa nie można było podważać zasadności decyzji władzy. Dodać należy, że niszczenie wróbli nie było jednym przykładem takiego skumulowanego działania zmierzającego do eksterminacji wybranego gatunku (tępiono tak też muchy, szczury). Analogiczna akcja w latach pięćdziesiątych odbywała się w Polskiej Rzeczpospolitej Ludowej, podjęto wtedy działania w celu wytępienia stonki ziemniaczanej, którą przez „skrupulatną lustrację pól” zbierała w czynie społecznym do butelek szczególnie młodzież. Inwazyjny owad miał być zrzucony z samolotów przez lotników amerykańskich.

Chiński przypadek klęski ekologicznej spowodowanej zabijaniem wróbli ma bardzo wyraźny wymiar socjologiczny, to właśnie bowiem działający wtedy społeczny mechanizm uniemożliwiał dawanie rzetelnej informacji zwrotnej (system oparty na lęku i terrorze wymuszał udawane posłuszeństwo i nie było w nim miejsca na przyjmowanie krytycznych komentarzy). W ten sposób dysfunkcyjne pomysły były wzmacnianie, a system tłamsił próby wskazywania informacji zwrotnej - decydenci opierali swoje decyzje na zafałszowanych danych, które były dostosowywane do ich oczekiwań.

Człowiek, próbując kontrolować świat, ingeruje nie tylko w światy fauny i flory, ingeruje także w funkcjonowanie własnego gatunku. Tutaj niefortunnym przykładem niech będzie z kolei próba inżynierii społecznej podejmowana w Szwecji w latach siedemdziesiątych. W 1972 r. szwedzka partia socjalistyczna opublikowała manifest poświęcony rodzinie przyszłości. Jej główną osią miało być zapewnienie przez państwo takich warunków życiowych i takiego wsparcia socjalnego, które pozwalałyby obywatelom funkcjonować samodzielnie, bez uzależniania się od innych osób. Cel został osiagnięty - dobrobyt Szwedów pozwala im dzisiaj na funkcjonowanie w pojedynkę. Sytuacja ta doprowadziła jednak do negatywnych konsekwencji społecznych, paradoksalnie obniżających poziom dobrostanu ludzi. Szwedzkie społeczeństwo stało się skrajnie zatomizowanym zbiorem jednostek niemających kontaktów ze sobąponieważ w zasadzie te kontakty nikomu do niczego nie są potrzebne. Oczywiście okazuje się, że od strony emocjonalnej i psychologicznej ludziom, jako

${ }^{18}$ Por. Manzoor Butt, Sajid (2018): 173.

19 Peng (1987). 
istotom społecznym, kontakt z innymi jest jednak potrzebny. Szwedzkie społeczeństwo ma największy na świecie odsetek jednoosobowych gospodarstw domowych, ponad połowa obywateli - najwięcej na świecie - mieszka sama. Indywidualizacja życia sprzyja uruchamianiu się ruchów typu New Age - neoplemienny charakter tych grup ma być właśnie antidotum na doświadczanie utraconych więzi społecznych.

W kontekście powyżej przytoczonych prób reżyserowania obecności różnych gatunków i modyfikowania ich sposobów funkcjonowania bardzo niepokojacco rysują się scenariusze, z którymi możemy mieć do czynienia wobec uchwalonej 19 grudnia 2019 r. ustawy ws. zwalczania afrykańskiego pomoru świń przez masową eksterminację dzików.

\section{ASF - METODY ZWALCZANIA CHOROBY}

W świetle naukowej wiedzy na temat afrykańskiego pomoru świń należy wskazać, że znacząco więcej sensu pod względem skuteczności ma zapobieganie pojawieniu się choroby niż usuwanie skutków jej obecności, już po pojawieniu się ognisk. W literaturze przedmiotu wskazywane są trzy zasadnicze metody działania, o różnym poziomie skuteczności. Niezależnie od uznawanych założeń normatywno-dyrektywalnych w ujęciu racjonalnym jest oczywiste, że podejmowanie działań ad hoc szczególnie w przypadku tej choroby jest bezcelowe. Standardowe formy zapobieganie ASF przyjmują następujące formy:

- bioasekruracja;

- ograniczanie populacji dzików przez odstrzał sanitarny (aż do eksterminacji gatunku);

- tworzenie fizycznych barier w rodzaju płotów, ogrodzeń;

- eliminowanie chorych stad świń.

\section{BIOASEKRURACJA}

Jedyną metodą skutecznego zwalczania ASF jest wprowadzenie, zastosowanie i rygorystyczne przestrzeganie zasad bioasekuracji, które byłyby ujednolicone dla całego kraju ${ }^{20}$. Wdrażanie tej metody wiąże się z koniecznościa modyfikowania postaw ludzkich i edukacją osób zajmujacych się produkcja trzody chlewnej, a nie sa to zadania łatwe. Zapewne ze względu na to nie sa to działania aktywnie wspierane przez polski rząd i instytucje, których funkcjonowanie ma na celu ochronę zdrowia zarówno zwierząt, jak i konsumentów. Być może także dlatego liczni przedstawiciele dużych producentów trzody chlewnej, ale i małych gospodarstw rolnych domagaja się odstrzału sanitarnego dzików prowadzącego do eksterminacji gatunku. Wprowadza-

\footnotetext{
${ }^{20}$ Por. Markowska-Daniel, Pejsak (2014).
} 
nie zasad bioasekuracji wymaga także aktywności własnej od producentów trzody chlewnej, a zmiana swoich przyzwyczajeń i nawyków nie jest psychologicznie prostym procesem. Podczas kiedy duże chlewnie sa w stanie finansowo podołać wprowadzaniu bioasekuracji, małe gospodarstwa rolne maja trudności z pokryciem kosztów innowacji. Według raportu Najwyższej Izby Kontroli ${ }^{21}$ średni koszt wprowadzenia bioasekuracji został określony na poziomie 33 tys. złotych, co nawet przy dofinansowaniu ze strony państwa jest kwota duża. Niestety, jak wskazano w raporcie, $74 \%$ badanych gospodarstw nie posiadało niezbędnych zabezpieczeń zapobiegających rozprzestrzenianiu się choroby ASF u świń: „rozwiązań w zakresie stosowania biosaekuracji nie dostosowano do rozdrobnionej struktury gospodarstw - w $93 \%$ były to małe, utrzymujące do 50 sztuk świń, gospodarstwa, których nie było stać na inwestycje. Dlatego właściwe zabezpieczenia przeciwepizootyczne mogło realnie wdrożyć zaledwie około 6\% właścicieli gospodarstw. Najwyższa Izba Kontroli zauważa, że właścicielom gospodarstw w ramach programu umożliwiono dobrowolną rezygnację z utrzymywania świń i zapewniono za to rekompensaty przez okres trzech lat. Wystarczyło, że złożyli oni oświadczenia o niespełnianiu wymogów właściwego zabezpieczenia gospodarstwa. Jednakże niewielu posiadaczy świń skorzystało z tej możliwości”.

Wprowadzenie zasad bioasekuracji, takich jak: ograniczanie kontaktu osób postronnych ze zwierzętami, tworzenie śluz utrudniających dostęp do chlewni ludziom, ale także sprzętowi rolniczemu, uniemożliwianie dostępu zwierząt domowych do chlewni, zapobieganie pojawianiu się gryzoni, stosowanie odzieży ochronnej, stosowanie środków biobójczych czy ograniczanie kontaktu trzody z otoczeniem zewnętrznym - oznacza daleko idące kontrolowanie zachowań ludzi, ale i zwierząt, bo w praktyce uniemożliwia prowadzenie chowu w warunkach ekstensywnych. Ponadto przestrzeganie zasad higieny i bioasekuracji w zasadzie wyklucza możliwość uboju gospodarskiego. Zasady bioasekuracji nie były ani nie są w Polsce wprowadzone systematycznie i konsekwentnie, a najbardziej widoczne jest to na przykładzie małych gospodarstw rolnych. Niezwykle problematyczne jest wprowadzenie takiej bioasekuracji w działaniach agroturystycznych i prowadzących edukację przyrodniczą z udziałem świń. Osobnym tematem pozostaje bezpieczeństwo świń utrzymywanych jako zwierzęta towarzyszacee, co nie jest rzadkością 22 .

Działania podejmowane w Polsce w zakresie prewencji rozprzestrzeniania ASF marginalizują rolę bioasekuracji, bagatelizując ją. Działania, które są podejmowane maja charakter fasadowy, choć wydają się radykalne ze względu na formę, która jest widoczna dla wszystkich, w tym i dla postronnych obserwatorów. Spektakularność polowań czy budowania płotów może tworzyć wrażenie rozwiązań znacznie bardziej skutecznych niż instalowanie urządzeń i barier bioasekuracyjnych czy wprowadzanie zasad bioasekuracji w zachowaniu ludzi. W Polsce podejmujemy jedynie działania zorientowane na elimi-

${ }^{21}$ Raport Najwyższej Izby Kontroli: Realizacja programu bioasekuracji jako element zwalczania afrykańskiego pomoru świń. Raport Najwyższej Izby Kontroli (2017).

${ }^{22}$ Hager, Rekiel (2015). 
nowanie rezerwuaru ASF lokalizowanego w dzikach. Bardzo enigmatycznie w wielu źródłach podawane są informacje na temat tego, że wirus „rozprzestrzenił się" - pomijając fakt, że rozprzestrzenienie wirusa jest możliwe dzięki jego fizycznemu transferowi. Pierwszy przypadek ASF w Polsce, który został wykryty w małym gospodarstwie liczaccym osiem świn, został zawleczony do tegoż gospodarstwa przez człowieka.

\section{EKSTERMINACJA LUB OGRANICZANIE POPULACJI DZIKÓW}

Takim rodzajem działania, które musi budzić i budzi kontrowersje etyczne, ale i sprzeciw oparty na przesłankach wynikających z racjonalnych analiz, jest propozycja przeprowadzenia $\mathrm{w}$ Polsce eksterminacji dzika przez organizacje wielkoobszarowych polowań sanitarnych. Tego rodzaju działania postulowane przez rolników nie moga przynieść skutku i każdy, kto zajmuje się tematyka rozprzestrzeniania się zoonoz w racjonalny i rzeczowy sposób, o tym wie. Jak wskazałam wcześniej na przykładzie zrealizowanego w Chińskiej Republice Ludowej projektu eksterminacji wróbla, wybicie innego gatunku także może przyczynić się do powstania zupełnie nieprzewidywalnych zjawisk. Tego rodzaju działania przynoszą nieopisane straty w ekosystemach, ponieważ zaburzają ich naturalną (o ile taka jeszcze jest możliwa) gospodarkę i równowagę (innym przykładem takiej niefortunnej ingerencji było wprowadzenie królików do Australii).

Prowadzenie polowań wielkoobszarowych, które w praktyce przyjmują postać zbiorowych polowań z nagonka, prowadzi do sytuacji niekontrolowanego i chaotycznego przepłaszania zwierząt, w tym - co nieuniknione - postrzałków. Szczególnie te zranione zwierzęta, jeśli byłyby nosicielami wirusa, stanowia istotne zagrożenie, roznoszenie choroby przez nie jest bowiem wysoce prawdopodobne. Czynnikiem, który mógłby tu być elementem ograniczajacym przenoszenie wirusa, jest ogradzanie ognisk choroby i zabijanie w nich uwięzionych zwierzat. Drugim słabym elementem w polowaniach sanitarnych jest czynnik ludzki: jak wskazuja liczne doniesienia w mediach, przestrzeganie bioasekuracji jest problemem nie tylko dla producentów trzody chlewnej, lecz także dla myśliwych, którzy nie dbaja o to, by zasad przestrzegać - nie kontroluja zachowania psów, nie dbają o odkażanie swojej odzieży i używanych przedmiotów, niedbale przewożą tusze zabitych zwierząt itd.

\section{ELIMINOWANIE CHORYCH ŚWIŃ}

W przypadku zdiagnozowania występowania ASF u trzody chlewnej zabijane jest i poddawane utylizacji całe stado, jako że afrykański pomór świń jest chorobą zwalczana z urzędu. Dla producentów trzody chlewnej są to oczywiste straty finansowe. Dla osób analizujących zagadnienie od strony etycznej jest to 
niewyobrażalna tragedia poświęcająca dla ludzi życie zwierząt. Dla zwierząt: jest to niezawiniona tragedia utraty życia. Przez masowego konsumenta rzecz widziana jest jako utrata potencjalnego produktu i marnowanie żywności.

Bardzo ponure jest to, że przez ASF istotnie zagrożone sa rasy rodzime świń. Niewiele się o tym mówi albo w ogóle nie porusza się tego aspektu ${ }^{23}$. Rasy rodzime, takie jak złotnicka pstra, puławska czy złotnicka biała, sa unikalne, objęte są bazującym na środkach Unii Europejskiej programem ochrony zasobów genetycznych, polegajacym na dopłatach do posiadanych loch. Problem polega na tym, że utrzymywane one sa głównie w systemach ekstensywnych, ekologicznych i dlatego tak bardzo są narażone na ASF, ponieważ hodują je często pasjonaci, niedysponujący tak znaczącymi środkami finansowymi, jakimi dysponują duże koncerny mięsne. Jeśli te łaciate świnie ras rodzimych pierwotnych wygina, ich odtworzenie nie będzie możliwe.

Innym jeszcze problemem związanym z ASF, o którym się nie mówi, jest fakt, że ściółka jest rezerwuarem wirusa, dlatego powoli rozpoczyna się przekonywanie rolników, by inwestować w systemy bezściołowe. To zaś oraz zakazy utrzymania świń na wybiegach nie sprzyjają ich dobrostanowi i generuja dalsze problemy w behawiorze, a co za tym idzie - utrzymywaniu zwierząt.

\section{TWORZENIE FIZYCZNYCH BARIER: PLOTY}

Wykrycie przypadków ASF w listopadzie 2019 w województwie lubuskim, a w grudniu 2019 r. w województwie wielkopolskim sprowokowało władze Polskie do podjęcia działań przyjmujących postać tworzenia fizycznych barier w tym przypadku na granicy województwa lubuskiego i wielkopolskiego postawiony został płot z siatki leśnej, o wysokości $180 \mathrm{~cm}$, obciążony na dole belka, która ma uniemożliwiać dzikom podnoszenie siatki i przechodzenie pod nią. Efektywność tego rodzaju płotu jest wątpliwa, ponieważ dziki są w stanie się pod nia podkopać, z kolei mniejsze zwierzęta (takie jak lis), które moga być wektorem ASFV, mogą swobodnie przecisnąć się przez oka siatki.

Wykryte w Polsce przypadki ASF wywołały także reakcję Niemiec, gdzie 20 grudnia 2019 r. rozstawiony został płot okolicach Guben na 120-kilometrowym odcinku granicy polsko-niemieckiej. Jest to forma elektrycznego pastucha o wysokości $90 \mathrm{~cm}$. Jest mobilny i można dokładać do niego nowe elementy. Rozproszone zostały także substancje zapachowe niedźwiedzi, wilków i rysiów, które mają odstraszyć dziki. Ta forma ogrodzenia wydaje się znacznie efektywniejsza niż jej Polska wersja, której skuteczność nie może być znacząca.

Stawianie płotów mających uniemożliwiać migrację zwierzętom chyba najintensywniej praktykowała Australia. Postawione tam dwa płoty miały uniemożliwić migrację psom dingo oraz królikom. Obydwa gatunki zosta-

${ }^{23}$ Bardzo dziękuję prof. UR dr. hab. Jackowi Nowickiemu z Uniwersytetu Rolniczego im. Hugona Kołłątaja w Krakowie za konsultacje merytoryczne tego tekstu, szczególnie za wskazanie problemu rodzimych ras polskich trzody chlewnej. 
ły zdefiniowane przez Australijczyków jako szkodniki przywleczone spoza kontynentu. W obu przypadkach zachowanie skuteczności płotów wymagało prowadzenia stałego nadzoru, opierającego się na międzystanowej współpracy. Sytuacja nadmiarowego grodzenia i uniemożliwiania zwierzętom migracji ujawniła swoje najbardziej negatywne konsekwencje w styczniu $2020 \mathrm{r}$. w trakcie pożarów w Australii. Wiele zwierząt zginęło właśnie dlatego, że nie były w stanie pokonać tych fizycznych barier.

Skuteczność płotów jest kwestionowana - dzisiejsze badania wskazuja, że wykorzystanie samego płotu nie przynosi pożądanych efektów i konieczne jest łączenie różnych metod ograniczania populacji niepożądanego zwierzęcia (tzw. metody letalne, a więc strzelanie oraz chwytanie w pułapki) ${ }^{24}$. Płoty w rodzaju omówionych przykładów australijskich są mało skuteczne w zatrzymywaniu migracji zwierząt, wydaje się, że byłyby jeszcze mniej skuteczne w ograniczaniu migracji wirusa, który przecież może być przenoszony przez owady. Ekolodzy wskazują ponadto negatywne konsekwencje stawiania płotów dla ekosystemów, podkreślając, że ograniczają one migracje różnych gatunków zwierząt, co przyczynia się do spadku bioróżnorodności.

\section{SPOŁECZNE ASPEKTY WALKI Z ASF}

Jak powyżej wskazałam, eksterminacja dzika jako gatunku nie jest trafna propozycją rozwiązania problemu rozprzestrzeniania się wirusa ASF. Jest natomiast rodzajem podejścia wpisującego się wyraźnie w dominacyjne podejście do natury, takie o którym mówili Mao Zedong i Chińska Partia Komunistyczna, promując „zwycięstwo ludzi nad natura”. Traktowanie natury (przyrody) jako wroga automatycznie wytycza sposób postępowania - z wrogiem się walczy, a nie współpracuje. Takie podejście jest wynikiem postrzegania świata na dymensji słaby-silny, charakterystycznego dla osobowości autorytarnych ${ }^{25}$. Tendencja do podporządkowywania natury ludziom jest charakterystyczna dla religii monoteistycznych oraz dla totalnych systemów władzy, a także dla osób o autorytarnym rysie osobowości. Foucoultowska koncepcja wiedzy - władzy znajduje tutaj bardzo szerokie zastosowanie.

Michel Foucault uznawany jest za twórcę dwóch ściśle ze sobą powiązanych terminów - biowładza i biopolityka. Biopolityka oznaczać ma świadome wykorzystanie biowładzy (wiedzy na temat biologii, w tym i ekologii, szczególnie człowieka) do realizowania konkretnych celów, ale przede wszystkim $\mathrm{w}$ celu zarządzania populacjami ludzkimi ${ }^{26}$. Biopolityka obejmuje zatem specyficzny rodzaj relacji pomiędzy polityka, rozstrzygnięciami prawnymi, stosunkami ekonomicznymi i podbudowa aksjologiczno-filozoficzna. Sama biopolityka ma służyć rozstrzyganiu kwestii spornych i etycznie dyskusyjnych, ale

\footnotetext{
24 Pacioni (2018).

25 Sontag (1989): 61.

${ }^{26}$ Zacher (2009): 95.
} 
w końcowym efekcie jest po prostu narzędziem zarządzania i formą sprawowania władzy - nie tylko nad grupami społecznymi, ale i nad i sposobem życia jednostki. Biopolityka bywa interpretowana jako „biologia polityki” (zmierzająca ku analizom biologicznych aspektów polityki i osób w niej uczestniczących) lub też jako „polityka biologii” (kierująca się ku reżyserii biologicznych aspektów ludzkiej populacji).

Niebagatelną rolę pełni więc $\mathrm{w}$ biopolityce dostęp do środków masowego przekazu. Przykładem procedury, której realizowanie jest uzasadniane poprzez prowadzenie odpowiedniego dyskursu publicznego, jest praktyka polowań na zwierzęta. Potrzebę polowań uzasadnia się na wiele różnych sposobów ${ }^{27}$, jednak wszystkie one wpisują się w ramy tego samego mechanizmu manipulacyjnego. Polega on na wzmacnianiu poczucia zagrożenia przez prezentowanie odpowiednich informacji przy użyciu mediów masowych.

W różnych scenariuszach przenoszenia ASF dopuszczany bywa także scenariusz bioterroryzmu, rozumianego jako intencjonalne i świadome rozprzestrzenianie bakterii, wirusów czy toksyn, które moga przyczynić się do wypadków śmierci ludzi, zwierząt i roślin (w niektórych krajach o totalitarnym systemie państwowości jest to już powszechna praktyka). O ile doniesienia medialne o dzikach znajdowanych na drzewach i zapewne zrzucanych z samolotów w celu rozprzestrzeniania wirusa ASF sa kuriozalnymi próbami generowania lęku zgodnie z teoriami spiskowymi (widać tutaj zaskakująca zbieżność z propagandą komunistyczną z czasów PRL, kiedy to utrzymywano, że amerykańscy lotnicy z samolotów zrzucają stonkę ziemniaczana), o tyle zaplanowany atak bioterrorystyczny jest możliwy do wykonania technicznie i jest nietrudny do przeprowadzenia ${ }^{28}$. Kontrolowanie takich wydarzeń wydaje się zupełnie niemożliwe. Jednak - jeśli taki scenariusz miałby być prawdziwy okazałoby się, że eksterminacja dzików byłaby zupełnie niepotrzebnym zabiegiem, który nie tylko że nie uchroniłby polskiej gospodarki przed zapaścia, ale także byłby zbytecznym kosztem.

Powracające rozstrzygnięcia polskiego rządu nakazujące eksterminację dzików budzą protesty zarówno świata nauki, jak i aktywistów prozwierzęcych, a także empatycznej części opinii publicznej. Działania rządu sa postrzegane jako uleganie presji lobby producentów trzody chlewnej oraz jako chęć pozyskania przychylności elektoratu rekrutującego się z kręgów producentów rolnych. Szeroko krytykowane jest instrumentalne wykorzystanie zwierząt (dzików), które stały się kozłem ofiarnym w całej tej sytuacji. Dwoista jest także ocena sytuacji przez Polski Związek Łowiecki (PZŁ), który jako organizacja znajduje się w trudnej sytuacji podległości wobec rozstrzygnięć ustawowych nakazujących jego członkom wykonanie eksterminacji dzika. Z jednej strony PZŁ przeciwstawia się takim działaniom, które interpretuje jako niezgodne z kodeksem etycznym PZÆ. Z drugiej jednak strony kieruje wnioski do swoich członków o intensyfikację polowań. Problematyczny jest także fakt, że członkowie PZ€ poluja, wykonując wyrok na dzikach i często całkowicie ignorując zasady bioasekuracji.

27 Kruczyński (2009); Rancew-Sikora (2009).

28 Brown, Bevins (2018); Jarynowski et al. (2019). 


\section{PODSUMOWANIE}

W obliczu obecności afrykańskiego pomoru świń wydaje się, że koncepcja jednego zdrowia do Polski nie dotarła. I mimo że w krajach anglosaskich i na zachodzie Europy jej wartość coraz mocniej się ugruntowuje, propozycje niwelowania zagrożenia ASF, które formułuje się w Polsce wydaja się nie tylko nieadekwatne, ale wręcz zaskakująco zaściankowe. Do tego stopnia, że staje się oczywiste, że nie moga to być racjonalne propozycje rozwiązywania proble$\mathrm{mu}$. Sa to propozycje sztafażowe, które mają służyć czemu innemu niż jedno zdrowie.

Zachowanie zdrowia na skalę globalna powinno być traktowane jako priorytet, o który można dbać jedynie dokładnie monitorując style życia ludzi. Oczywiste jest, że idea jednego zdrowia może być z sukcesem popularyzowana tylko w sytuacji współpracy międzydziedzinowej, pozwalającej na holistyczne ujmowanie zjawisk w szeroki socjopolitycznym kontekście, który warunkuje działania ludzi. Tylko takie podejście może zaproponować bardziej zintegrowane, całościowe działania, które przyniosą rzeczywiste efekty i podniosa skuteczność programów chroniących zdrowie i zapobiegających chorobom.

W szeroko zaprezentowanym w tym tekście kontekście, którym jest pojawienie się i rozprzestrzenianie ASFV, wydaje się, że prewencja, a szczególnie intensyfikacja badań nad opracowaniem szczepionki wydają się kluczowymi działaniami mogącymi zażegnać problem. Z pewnością takie działania, jak eksterminacja dzików, nie pozwolą na uporanie się z kłopotem.

Kiedy eksterminacja jakiegokolwiek gatunku staje się metodą rozwiązania problemu, wkraczamy na bardzo niebezpieczne obszary działania, prowadzace do strasznych konsekwencji. Niemal naturalnie nasuwa się pytanie: Dzisiaj zabijamy dziki, a na jaki gatunek padnie oskarżenie jutro? W odpowiedzi na głosy wskazujące, że populacja dzików jest zbyt duża, że zwierzęta te nie mają dziś naturalnych wrogów oprócz człowieka, a mają natomiast niespotykany dotąd dostęp do bazy żerowej, sprzyjające rozrodowi zmiany ocieplającego się klimatu oraz znaczne zdolności adaptacyjne, pozwalające dzikom funkcjonować nawet w miastach i zwiększać potencjał reprodukcyjny (dwie ruje w roku), przypomnieć należy, że wszystko to jest możliwe dzięki wcześniejszym działaniom człowieka. Dzięki programowemu tępieniu naturalnych wrogów - wilków, dzięki antropopresji i dzięki produkcji zwierzęcej generującej zmiany klimatyczne.

Hanna Mamzer

Uniwersytet im. Adama Mickiewicza w Poznaniu

mamzer@amu.edu.pl

https://orcid.org/0000-0002-2251-7639 
Brown, V.R., Bevins, S.N. (2018). A Review of African Swine Fever and the Potential for Introduction into the United States and the Possibility of Subsequent Establishment in Feral Swine and Native Ticks. Frontiers in Veterinary Science 5. doi:10.3389/fvets.2018.00011.

De Mello, M. (2012). Animals and Society: An Introduction to Human-Animal Studies. New York: Columbia University Press.

Destoumieux-Garzón, D., Mavingui, P., Boetsch, G., Boissier, J., Darriet, F., Duboz, P., Fritsch, C., Giraudoux, P., Le Roux, F., Morand, S., Paillard, Ch., Pontier, D., Sueur, C., Voituron, Y. (2018). The One Health Concept: 10 Years Old and a Long Road Ahead. Frontiers in Veterinary Science 5. <www.frontiersin.org/article/10.3389/fvets.2018.00014>.

Frant, M., Woźniakowski, G., Pejsak, Z. (2017). African swine fever (ASF) and ticks: no risk of tick-mediated ASF spread in Poland and Baltic states. Journal of Veterinary Research 61(4): $375-380$.

Goffman, E. (2005). Piętno. Tłum. A. Dzierżyńska, J. Tokarska-Bakir. Gdańsk: Gdańskie Wydawnictwo Psychologiczne.

Hager, D., Rekiel, A. (2015). Świnie miniaturowe - zwierzęta towarzyszące. Wiadomości Zootechniczne 53(3): 180-191.

Harrison, R. (2013). Animal Machines: The New Factory Farming Industry. Publisher: CABI.

Holst, A. (2016). Chinese Propaganda Posters in Mao's Patriotic Health Movements: From Four Pests to SARS. <https://www.academia.edu/35083393/Chinese_Propaganda_Posters_in_ Maos_Patriotic_Health_Movements_From_Four_Pests_to_SARS >.

Jarynowski, A., Płatek, D., Krzowski, Ł., Gerylovich, A., Belik, V. (2019). African Swine Fever-potential biological warfare threat. doi: 10.13140/RG.2.2.32360.62725.

Kruczyński, Z. (2008). Farba znaczy krew. Gdańsk: Słowo/Obraz Terytoria.

Mamzer, H. (2018). Przyroda groźna? Biofobia jako usprawiedliwienie konieczności polowań. „Zoophilologica. Polish Journal of Animal Studies 4: 149-162.

Manzoor Butt, K., Sajid, S. (2018). Chinese Economy under Mao Zedong and Deng Xiaoping. Journal of Political Studies 25(1): 169:178.

Markowska-Daniel, I., Pejsak, Z. (2014). Afrykański pomór świń materiały szkoleniowe dla lekarzy weterynarii. <https://www.wetgiw.gov.pl/nadzor-weterynaryjny/afrykanski-pomor-swin>.

Mirbeau, O. (2003). Dingo. Editions du Boucher. Societe Octave Mirbeau.

Pacioni, C., Kennedy, M.S., Berry, O., Stephens, D., Schumaker, N.H. (2018). Spatially-explicit model for assessing wild dog control strategies in Western Australia. Ecological Modelling 368: 246-256. doi:10.1016/j.ecolmodel.2017.12.001.

Peng, X. (1987). Demographic consequences of the great leap forward in China's provinces. Population and Development Review 13(4): 639-670.

Rancew-Sikora, D. (2009). Sens polowania. Warszawa: Scholar.

Roncaglia, A. (2006). The Wealth of Ideas: A History of Economic Thought. Cambridge University Press.

Sontag, S. (1979). Illness as Metaphor. First Vintage Books Edition.

Sontag, S. (1989). AIDS and its Metaphors. Published by Allen Lane.

Sontag, S. (2016). Choroba jako metafora. AIDS i jego metafory. Kraków: Karakter.

Woźniakowski, G., Frączyk, M., Niemczuk, K., Pejsak, Z. (2016). Selected aspects related to epidemiology, pathogenesis, immunity, and control of African swine fever. Journal of Veterinary Research 60(2): 119-125. doi:10.1515/jvetres-2016-0017.

Zacher, L. (2009). Biowładza i biopolityka (refleksje, przykłady, predykcje), [w:] J. Szymczyk, M. Zemło, A. Jabłoński (red.), Wiedza - władza. Lublin: 101-112. 


\section{DISEASE AS A SOCIAL PHENOMENON: AN ANALYSIS OF THE FIGHT AGAINST AFRICAN SWINE FEVER}

\section{S u m m a r y}

African swine fever is undoubtedly an extremely dangerous disease for swine and boars. It also causes major economic loss. However, in Poland the fight against the disease seems to have been used as an of instrument of social engineering. The solutions introduced in Poland - such as the extermination of the population of wild boars - will not provide the expected level of biosecurity. Methods that are recommended by experts worldwide focus on biosecurity, but this measure is not successfully enforced in Poland. A wider, socio-cultural analysis of how discourses related to ASFV and other diseases are used reveals that this is very complex phenomena.

Keywords: ASFV; African swine fever; manipulation; boar; biosecurity 
